\title{
弾性体の実効的な静摩擦係数に関する設計指針*
}

前川 覚*1, 糸魚川 文広*1, 新吉 隆利 ${ }^{* 2}$ 鈴木 厚 $^{* 2}$, 田所 千治 ${ }^{* 3}$, 中野 健 $^{* 3}$

\section{Design Criteria on Effective Static Friction Coefficient of Elastomers}

\author{
Satoru MAEGAWA, Fumihiro ITOIGAWA, Takatoshi SHINYOSHI, \\ Atsushi SUZUKI, Chiharu TADOKORO and Ken NAKANO*3 \\ ${ }^{* 3}$ Faculty of Environment and Information Sciences, Yokohama National University \\ 79-7 Tokiwadai, Hodogaya-ku, Yokohama-shi, Kanagawa, 240-8501 Japan
}

In sliding friction of elastomers, the effective static friction coefficient $\mu_{\mathrm{s}}^{\text {eff }}$ observed is not necessarily equal to the inherent real one $\mu_{\mathrm{s}}$ possessed by the material; usually $\mu_{\mathrm{s}}^{\text {eff }}<\mu_{\mathrm{s}}$ because of the elastic deformations of sliding objects and the propagation of shear fracture in the contact area. This indicates that focusing on elastic deformation of sliding objects can derive a new criterion of $\mu_{\mathrm{s}}^{\text {eff }}$ for machine design. In this study, mainly through numerical simulations for a physical model assured by experiments in which measuring frictional force and observing contact area were carried out for a longitudinal line contact of polymethyl methacrylate, it is found that the stiffness ratio $\kappa=K_{\mathrm{b}}{ }^{\text {tot }} / K_{\mathrm{c}}^{\text {tot }}$ (where $K_{\mathrm{b}}{ }^{\text {tot }}$ and $K_{\mathrm{c}}^{\text {tot }}$ are the total bulk stiffness and total tangential contact stiffness of the elastic sliding object, respectively) dominates the value of $\mu_{\mathrm{s}}^{\text {eff }}$.

Key Words : Elastomer, Contact, Deformation, Sliding Friction, Frictional Vibration, Stick-Slip, Global Slip, Partial Slip, Precursor, Friction Coefficient

\section{1. 緒 言}

機械システムの摺動部に要求される摩擦特性は多種多様である。軸受や案内面などのように，低摩擦であ ることが求められる場合もあれば，夕イヤやクラッチをはじめとする動力伝達部のように，高摩擦を維持す ることが必要となる場合もある。また，スティックスリップなどの摩擦振動を回避するためには，静摩擦力 と動摩擦力の差をできる限り小さくすることや，動摩擦力の相対速度依存性を正にすることなどが求めら机 $ろ^{(1)(3)}$. このような状況の中，いかに所望の摩擦特性を実現させるかが，摺動部の設計の生命線となる.

一般に, 所望の摩擦係数を得るための設計指針とは，材料の変更や表面改質または潤滑剤 (基油と添加剤) の変更などのように，摺動部のインターフェイスに着目したアプローチのことを指す。これらの手法に共通 することは，摺動部の真実接触面積または真実接触部の剪断強さを増減することで，インターフェイスの摩 擦特性そのものを調整するという考方方にある.

一方，弾性体のすべり摩擦では，「実効的な静摩擦係数（システムに現れる見掛けの静摩擦係数）は真の静 摩擦係数 (インターフェイスが持つ本来の静摩擦係数) よりも低く現れる」ことが近年指摘されている ${ }^{(4)(6)}$. 例えば，Maegawa ら ${ }^{(4)} は ， F i n e b e r g ら^{(7)(9)} に よ り$ 開発された接触面可視化手法を利用して，アクリル製のスラ イダとベースブロックで構成される線接触部の in-situ 観察を偏荷重下で行い，スライダを離散的にモデリン グして得た数值解析との比較から, 実効的な静摩擦係数を決める要因として, スライダの弾性的な内部変形

* 原稿受付 2013 年 1 月 30 日

*1 正員, 名古屋工業大学 ( $=466-8555$ 愛知県名古屋市昭和区御器所町)

*2 トヨ夕自動車 (株) ( T471-8572 愛知県豊田市トヨ夕町 1 番地)

*3 正員，横浜国立大学（广240-8501 神奈川県横浜市保土ヶ谷区常盤台 79-7)

E-mail: nakano@ynu.ac.jp 
と接触部を伝播する剪断破壊の重要性を指摘している。このことは,「インターフェイスのミクロな性質に着 目した（従来の）摩擦の設計」とは別に,「バルクのマクロな変形に着目した（新たな）摩擦の設計」があり 得ることを示唆している.

以上の背景を踏まえて本研究では，後者のコンセプトの是非を検討するために，アクリル製のスライダと ベースブロックのすべり摩擦を対象として, 実験と数值解析を行った。 実験では, 線接触部の可視化により 剪断破壊の伝播を確認しながら, 実効的な静摩擦係数に及ぼすスライダ長の影響を調べた。数值解析では, Maegawa らのモデル(4)の汎化性を高めた Amundsen らのモデル(10)を採用して, 実効的な静摩擦係数に及ぼす スライダの弾性変形の影響を調べた。その結果, 「スライダのバルク剛性と接線方向の接触剛性の比」が実効 的な静摩擦係数を支配することを見出した，以後，その詳細を報告する。

\section{2. 実験方法}

\section{$2 \cdot 1$ 試験片}

試験片として，透明なアクリル（ヤング率：2.5 GPa）製のスライダと，同アクリル製のベースブロックを 用いた。 そ机らの模式図を図 1 に示す。スライダの下面には，X方向に沿って頂角 158 度の面取り加工が施 されている，スライダの下面とベースブロックの上面は，サンドペーパによる $Y$ 方向の研磨により, 異方的 な表面粗さ $\left(X Z\right.$ 平面で切断した断面曲線の自乗平均粗さ $\left.: R_{\mathrm{q}}=1.30 \mu \mathrm{m}\right)$ を有する. 本実験では, スライダ の下面とベースブロックの上面で構成される線接触部 (接触長 $: L=25 \mathrm{~mm}, 50 \mathrm{~mm}, 100 \mathrm{~mm}$, 接触幅: $0.8 \mathrm{~mm}$ ) を利用した。

\section{$2 \cdot 2$ 実験装置}

実験装置の構成を図 2 に示す．本装置は，スライダとベースブロック (正面図の中央), 垂直方向負荷ユニ ット (正面図の右側), 接線方向負荷ユニット (正面図の左側) からなる. スライダはベースブロックの上に 置かれており, ベースブロックは装置中央の鋼製のホルダで固定されている.

垂直方向負荷ユニットは, 垂直荷重 $\left(F_{Z}\right)$ を計測する 2 個のロードセル $(Z) （ 1$ 個あたりの剛性 $\left.: 0.8 \mathrm{MN} / \mathrm{m}\right)$ と, それらを鉛直方向に駆動する自動ステージ（Z）からなる. 並列する 2 個のロードセルは, 軸間距離を $60 \mathrm{~mm}$ として，上部は鋼製のブラケット，下部は鋼製の板で固定されている．同ブラケットは，傾斜ステー ジを介して自動ステージ $(Z)$ の駆動部に固定されており, 同自動ステージは, 位置決め用の手動ステージ $(X)$ を介して定盤に固定されている.

接線方向負荷ユニットは，接線荷重 $\left(F_{X}\right)$ を計測するロードセル $(X)$ (剛性 $\left.: 0.8 \mathrm{MN} / \mathrm{m}\right)$ と，それを水平 方向に駆動する自動ステージ $(X)$ からなる，ロードセル $(X)$ は，その中心軸がスライダの中心軸と一致す るように，鋼製のブラケットを介して自動ステージ $(X)$ の駆動部に固定されている. 同自動ステージは, 位 置決め用の手動ステージ $(X)$ を介して定盤に固定されている.

2 個のロードセル $(Z)$ の下部を固定する鋼板とスライダの間には，ゴム製の板（ヤング率 $: 0.2 \mathrm{MPa}$ ，厚 さ：10 mm）が挟まれている.この柔軟なゴム板は，鋼板の下面とスライダの上面の形状誤差を吸収して， スライダに加わる垂直荷重分布のう㸚りを解消するとともに，スライダに接線荷重を加えることにより生じ るすべりをスライダとベースブロックの線接触部に限定する役割を担う.

本装置は，両負荷ユニットの配置と直交して，平面レーザ光源（波長： $532 \mathrm{~nm}$ ），コリメートレンズ，およ び高速度カメラからなる透過光学系を備えている(側面図参照).コリメートしたレーザシート (幅：120 mm, 厚さ $: 3 \mathrm{~mm}$ ) を入射光として, 入射角 62 度で線接触部を照射する。この入射角は, アクリルと空気の界面 での全反射角（42 度）よりも大きいので，スライダとベースブロックの真実接触部では入射光が透過して， 非接触部では全反射する. 従って, 線接触部からの透過光を時空間計測することにより, 真実接触面積の時 空間変化を得ることができる.

\section{$2 \cdot 3$ 実験手順}

まず，スライダとベースブロックを洗剤で洗浄した後，エタノール中で超音波洗浄して乾燥させた. 次に， ベースブロックをホルダに固定して，その上にスライダを垂直に置き，自動ステージ $(Z)$ を $Z$ 負方向に駆動 

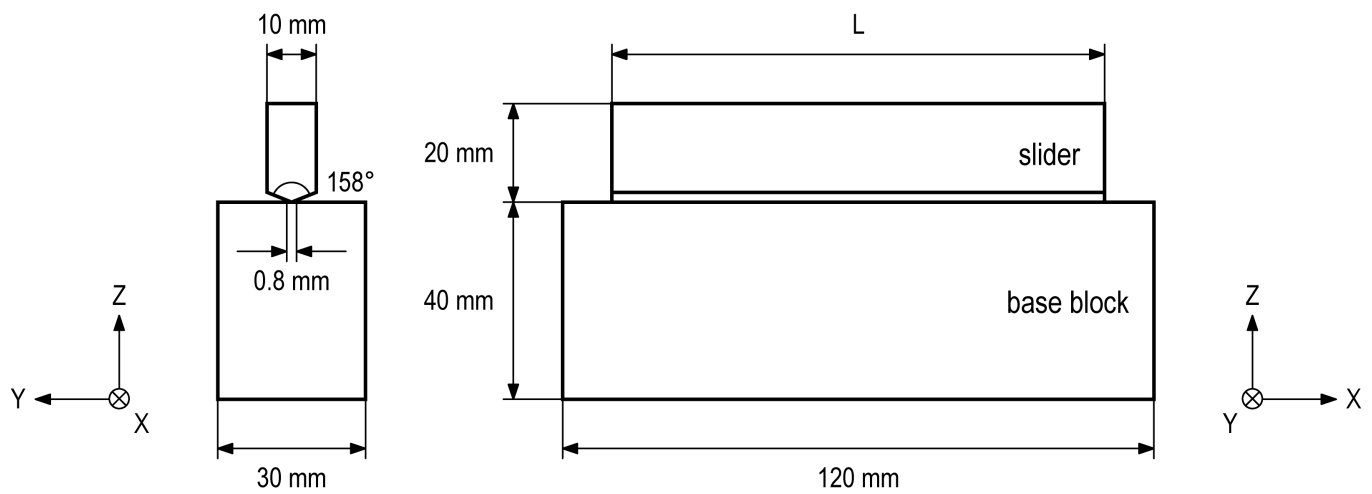

Fig. 1 Slider and base block; slider length $L=25,50$, or $100 \mathrm{~mm}$

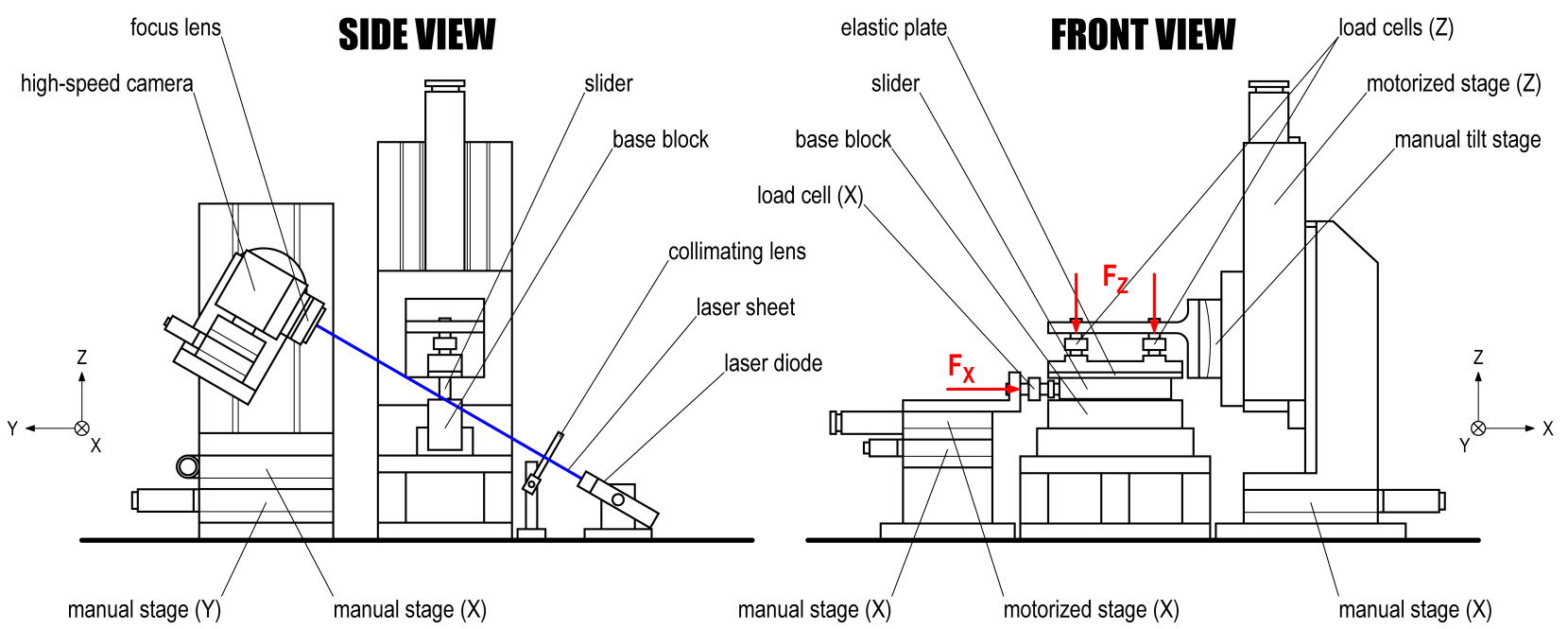

Fig. 2 Experimental apparatus

して，スライダに $F_{Z}=400 \mathrm{~N}$ の垂直荷重を加えた。ただし，2 個のロードセル（Z）の計測值がともに $200 \mathrm{~N}$ となるように，傾斜ステージを用いてブラケットの角度を調節した．垂直荷重を加えてから 200 秒間静置し た後, 自動ステージ $(X)$ を $X$ 正方向に速度 $V=0.1 \mathrm{~mm} / \mathrm{s}$ で駆動して, スライダに接線荷重 $F_{X}$ を加えた。同 時に，3 個のロードセルからの信号を $\mathrm{AD}$ 変換して，サンプリング速度 $500 \mathrm{~Hz}$ で記録した。

ロードセルによる力計測と同期して，線接触部からの透過光を高速度カメラで撮影した．撮影面積は，線 接触部の全域を網羅するように, $100 \mathrm{~mm}(X) \times 0.8 \mathrm{~mm}(Y)$ とした。 ただし，撮影画像の画素数は, 1000 ピクセル $(X) \times 4$ ピクセル $(Y)$ とした. 従って, 1 ピクセルあたりの撮影面積は, $0.1 \mathrm{~mm}(X) \times 0.2 \mathrm{~mm}(Y)$ に相当する。 また, 各画素が有する光強度の分解能は 256 階調である. なお, すべての実験は温度 $25^{\circ} \mathrm{C}$ お よび相対湿度 $30 \%$ の室内環境下で行った。

\section{3. 実験結果}

\section{$3 \cdot 1$ 典型的な実験結果}

スライダ長を $L=100 \mathrm{~mm}$ とした場合の実験結果を図 3 に示す。上段は, ロードセル $(X)$ が計測した $F_{X}$ の時間変化を表す。中段は, 各時刻 $t$ における撮影画像 $(1000$ ピクセル $(X) \times 4$ ピクセル $(Y))$ を $Y$ 方向に 平均して, 縦長な線画像 $(1000$ ピクセル $(X) \times 1$ ピクセル $(Y))$ を得た後, それらを横に連結して得た透過 光強度マップ $I(X, t)$ である. ただし, 透過光強度の時空間変化を際立たせるために, 各点での $I(X, t)$ を $I(X, 0)$ で規格化して, その值を RGBカラー 256 階調で表してある.下段は, 透過光強度の総和の時間変化 $I_{\mathrm{tot}}(t)$ を $I_{\mathrm{tot}}(0)$ で規格化して示したものである.

まず，ほぼ定常状態とみなせる $t=2.7 \mathrm{~s}$ 以降では， $F_{X}$ は線形的な増加と急激な低下を繰り返しており，低 


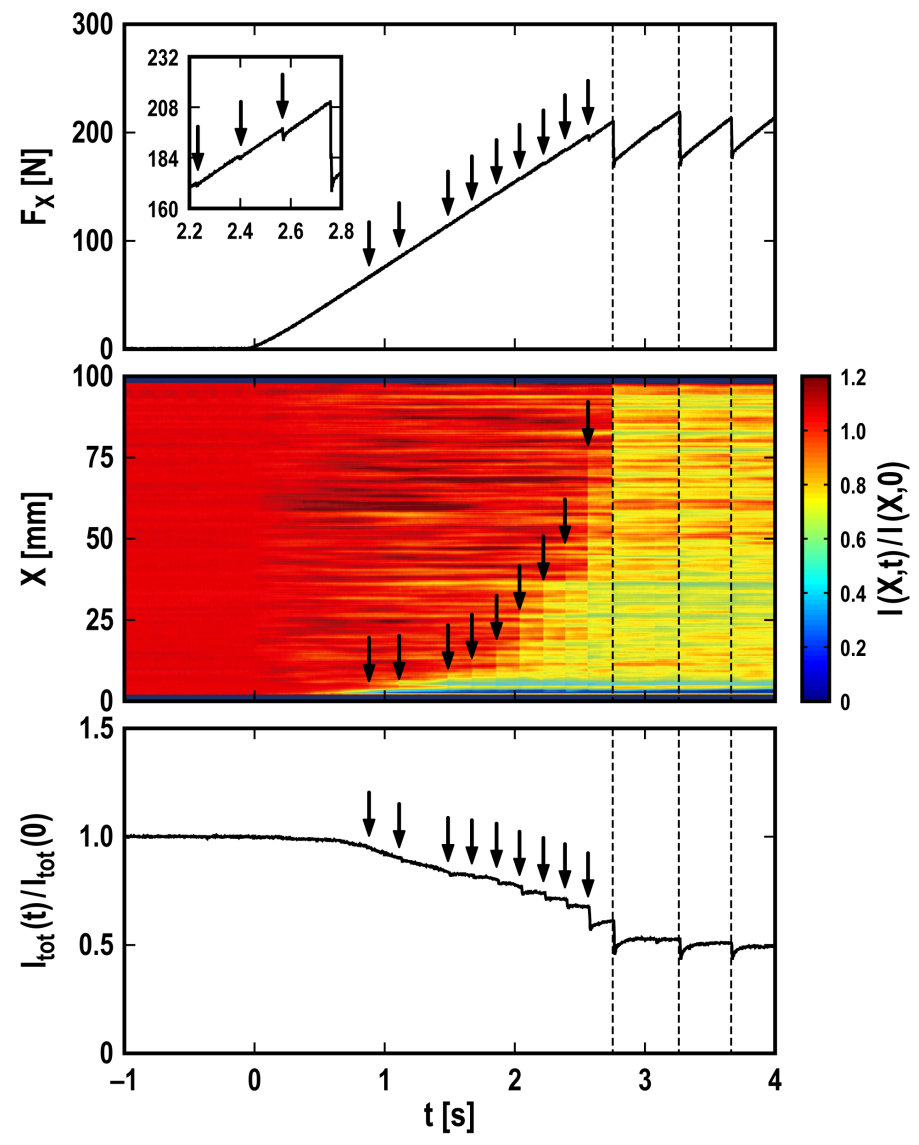

Fig. 3 Experimental results; temporal change in tangential load $F_{X}$ (top), temporal-spatial change in intensity $I(X, t) /$ $I(X, 0)$ of transmitted light from line contact (middle), and temporal change in total intensity $I_{\mathrm{tot}}(t) / I_{\mathrm{tot}}(0)$ of transmitted light (bottom); arrow: precursor and broken line: global slip; $L=100 \mathrm{~mm}$

速なすべり摩擦に典型的な鋸歯波状のスティックスリップが発生していることがわかる(3). $F_{X}$ に数十ニュー トン程度の急激な低下が現れる瞬間（図中の破線）には，中段の透過光強度マップにおいて，接触部後緑 $(X$ $=0 \mathrm{~mm})$ と前縁 $(X=100 \mathrm{~mm})$ を結ぶ筋が現れている。これは，固着した真実接触部の剪断破壊，すなわち 局所すべり（ミクロスケールでの固着すべり遷移）が接触部全域に伝播して，巨視すべり（マクロスケール での固着すべり遷移) が現れたことを示している(7). また，同じタイミングで下段の $I_{\mathrm{tot}}$ が低下していること は, マクロな意味での静摩擦から動摩擦への遷移において, 真実接触面積が瞬間的に減少することを意味し ている。

一方，過渡状態とみなせる $t=2.7 \mathrm{~s}$ 以前では，上段の $F_{X}$ と下段の $I_{\mathrm{tot}}$ において, 9 回の急激な低下（図中の 矢印）が同時に認められる。ただし， $F_{X}$ の低下幅は回を重ねるごとに成長するが, 最大でも数ニュートン程 度であり，巨視すべりでのイベントと比較すると，規模は 1 桁以上小さい.（これを前兆現象と呼ぶ.）前兆 現象が生じるとき, 中段の透過光強度マップには, 接触部後縁 $(X=0 \mathrm{~mm})$ から前縁 $(X=100 \mathrm{~mm})$ に向け て途中まで伸びる 9 本の筋が認められる。これらの筋の長さは回を重㸚るごとに成長するとともに, 透過光 強度の減少領域（赤色から黄色に変化する領域）もまた前緑側へと拡大している.

このような一連の前兆現象のメカニズムは，断続的に発生する部分すべりであると考号れている(4)(6)(9)(10). 接線荷重の増加にともない, 固着した真実接触部に作用する剪断力が接触部後縁付近で増大し, 接触部後縁 から開始した局所すべりが線接触部の途中まで瞬間的に伝播したものと考えられる。なお，サンプリング速 度を $100 \mathrm{kHz}$ とした高速度撮影により, その伝播速度が $1000 \mathrm{~m} / \mathrm{s}$ 程度 (すなわち, レイリー波速度と同程度) であることを確認した。

\section{$3 \cdot 2$ 実効的な摩擦係数に及ぼすスライダ長の影響}

接線力 $F_{X}$ の時間変化に及ぼすスライダ長 $L$ の影響を図 4 に示す. $F_{X}$ に現れる鋸歯波状のスティックスリッ 


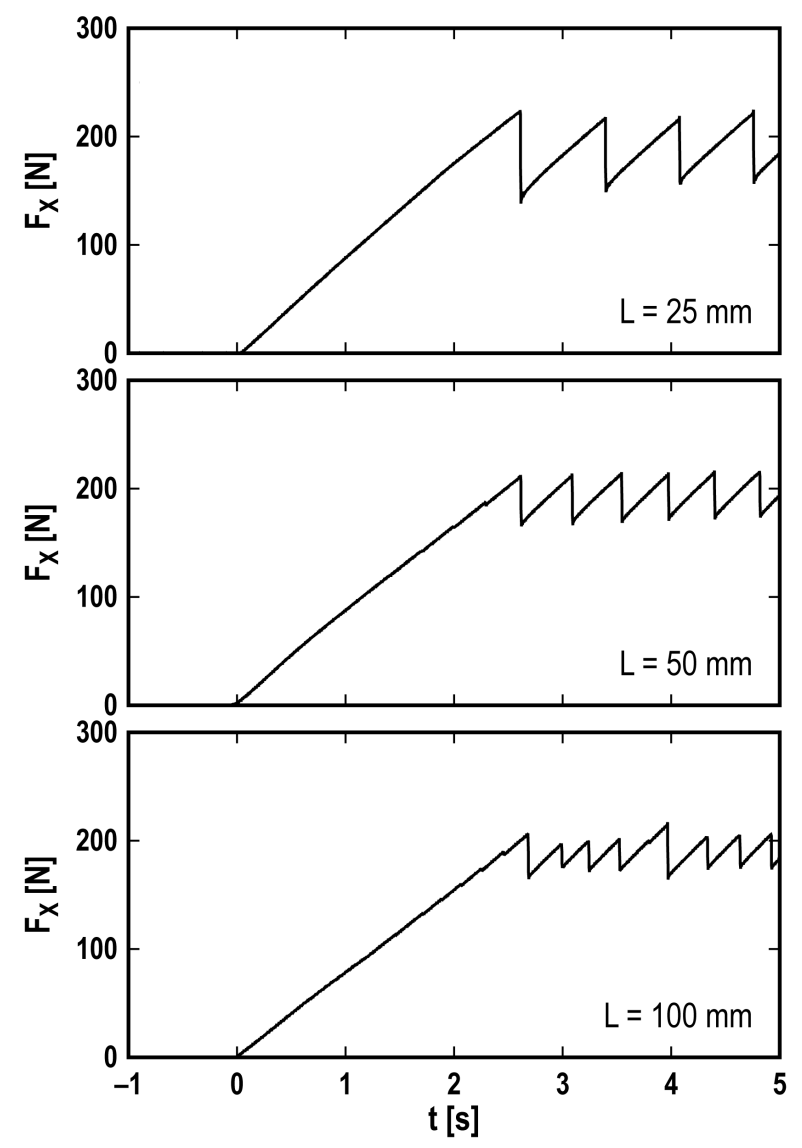

Fig. 4 Experimental results; effect of slider length $L$ on temporal change in tangential load $F_{X}$

プの振幅は， $L$ の増加にともない明確に減少している，スティックスリップの振幅の変化は，少なくとも実 効的な静摩擦係数 $\mu_{\mathrm{s}}^{\text {eff }}$ と実効的な動摩擦係数 $\mu_{\mathrm{k}}{ }^{\text {eff }}$ のいずれか一方の值に影響を及ぼす.

そこで, 同一条件での実験を 5 回繰り返して, 静摩擦から動摩擦への遷移の瞬間における $F_{X}$ の極大值（鋸 歯状波形の頂点）の平均を $F_{Z}$ で除すことにより $\mu_{\mathrm{s}}^{\mathrm{eff}}$ を算出したところ, $L=25 \mathrm{~mm}, 50 \mathrm{~mm}, 100 \mathrm{~mm}$ に対し て，それぞれ $\mu_{\mathrm{s}}^{\mathrm{eff}}=0.549 \pm 0.004,0.531 \pm 0.003,0.518 \pm 0.005$ であった。一方，最初の静摩擦から動摩擦への遷 移が生じた後の定常的な鋸歯状波形における $F_{X}$ の時間平均を $F_{Z}$ で除すことにより $\mu_{\mathrm{k}}^{\mathrm{eff}}$ を算出したところ, いずれのスライダの場合も $\mu_{\mathrm{k}}^{\mathrm{eff}}=0.470 \pm 0.003$ となった，従って，実効的な動摩擦係数はスライダ長によらず 一定であるのに対して，実効的な静摩擦係数はスライダ長と負の相関があることがわかる.

\section{4. 数值解析方法}

\section{4・1＼cjkstart解析モデルと運動方程式}

実効的な摩擦係数に及ぼすスライダのバルクの変形の影響を数值的に調べるために, Amundsen $ら^{(10)} に よ$ り提案された解析モデルを用いた。これは，凝着摩擦により生じるスライダの弾性変形に加えて，接線方向 の接触剛性を考慮したすべり摩擦のモデルであり, 先に Maegawa ${ }^{(4)}$ が観察した前兆現象の特徴をよく再現 することが知られている.

同モデルを図 5 に示す。 $N$ 個のブロック (質量 $: m$ ) を $N-1$ 個のばね（剛性 $: k$ ）とダッシュポット（減 衰係数：c）で直列に連結してスライダを表し，それに接する剛平面でベースブロックを表している．スライ ダの左端に配したばね（剛性： $K$ ） はロードセルを表し，その左端を一定速度 $V$ で右方向に駆動して，スラ イダに接線荷重 $F_{X}$ を加える．なお，各ブロックは，接線方向の接触剛性を表すばね（剛性： $k_{\mathrm{c}}$ ）を介して剛 平面と接触する. 各ブロックが支える垂直荷重を $w$ とし, 各接触点には, 剛平面との相対速度が零のとき静 摩擦力，相対速度が非零のとき動摩擦力が作用する. 


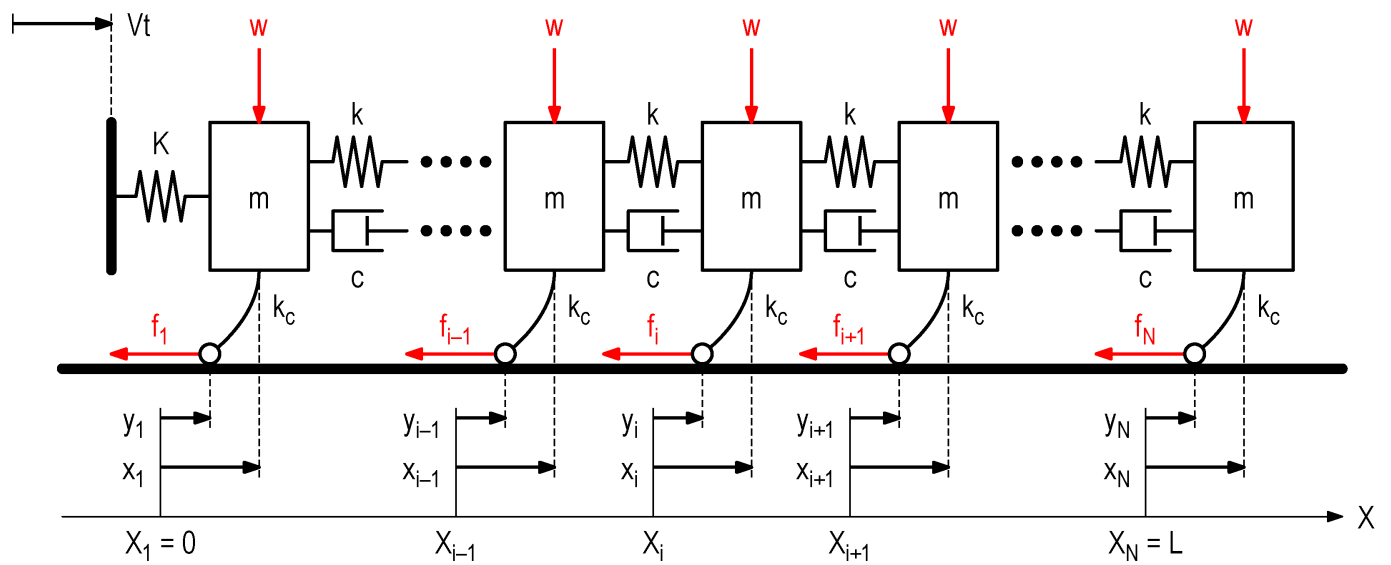

Fig. 5 Analytical model

左から $i$ 番目のブロックの位置を $x_{i}$ (ただし, すべてのばねを自然長とした初期状態での位置を原点 $\left.x_{i}=0\right)$ とすると，各ブロックの運動方程式は以下で与えられる.

$$
\left\{\begin{array}{cccc}
m \ddot{x}_{1}=K\left(V t-x_{1}\right)+k\left(x_{2}-x_{1}\right)+c\left(\dot{x}_{2}-\dot{x}_{1}\right)+f_{1} & \text { for } & i=1 \\
m \ddot{x}_{i}=k\left(x_{i+1}-2 x_{i}+x_{i-1}\right)+c\left(\dot{x}_{i+1}-2 \dot{x}_{i}+\dot{x}_{i-1}\right)+f_{i} & \text { for } & 2 \leq i \leq N-1 \\
m \ddot{x}_{N}=-k\left(x_{N}-x_{N-1}\right)-c\left(\dot{x}_{N}-\dot{x}_{N-1}\right)+f_{N} & \text { for } & i=N
\end{array}\right.
$$

ただし，各接触点に働く接線力（摩擦力） $f_{i}$ は, 左から $i$ 番目の接触点の位置を $y_{i}$ (ただし，すべてのばねを 自然長とした初期状態での位置を原点 $\left.y_{i}=0\right)$ として，アモントン・クーロン則に基づき以下で与える.

$$
f_{i}=\left\{\begin{array}{cll}
-k_{\mathrm{c}}\left(x_{i}-y_{i}\right) & \text { when } & \dot{y}_{i}=0 \\
-\mu_{\mathrm{k}} w & \text { when } & \dot{y}_{i}>0 \\
\mu_{\mathrm{k}} w & \text { when } & \dot{y}_{i}<0
\end{array} \text { and }-\mu_{\mathrm{s}} w \leq-k_{\mathrm{c}}\left(x_{i}-y_{i}\right) \leq \mu_{\mathrm{s}} w\right.
$$

ここで， $\mu_{\mathrm{s}}$ は（各接触点に作用する）真の静摩擦係数， $\mu_{\mathrm{k}}$ は真の動摩擦係数を表し， $\mu_{\mathrm{s}}>\mu_{\mathrm{k}}$ とする.

\section{$4 \cdot 2$ 計算条件}

運動方程式の数值解法にはルンゲ・クッタ法を用いた。諸パラメータの值は以下の関係に基づき定めた.

$$
\begin{aligned}
& m=\frac{M}{N} \\
& k=(N-1) K_{\mathrm{b}}^{\mathrm{tot}}=\frac{(N-1) E S}{L} \\
& k_{\mathrm{c}}=\frac{K_{\mathrm{c}}^{\mathrm{tot}}}{N} \\
& c=\sqrt{0.1 m k} \\
& w=\frac{F_{z}}{N}
\end{aligned}
$$

ただし， $M$ はスライダの質量， $K_{\mathrm{b}}{ }^{\mathrm{tot}}$ はスライダのバルク剛性， $S$ は $X$ 軸と垂直な平面におけるスライダの断 面積, $K_{\mathrm{c}}^{\text {tot }}$ は接線方向の接触剛性の総和を表す。減衰係数 $c$ は, 離散化により生じる計算誤差を抑えるため に，Amundsen らの報告(10)を踏まえて式(6)のように設定した。パラメータの基準值は，実験系にあわせて， $L$ $=100 \mathrm{~mm}, S=200 \mathrm{~mm}^{2}, E=2.5 \mathrm{GPa}, M / L S=1.2 \times 10^{3} \mathrm{~kg} / \mathrm{m}^{3}, \quad K_{\mathrm{c}}^{\text {tot }}=1000 \mathrm{MN} / \mathrm{m}, K=0.8 \mathrm{MN} / \mathrm{m}, \quad F_{Z}=400 \mathrm{~N}$, 


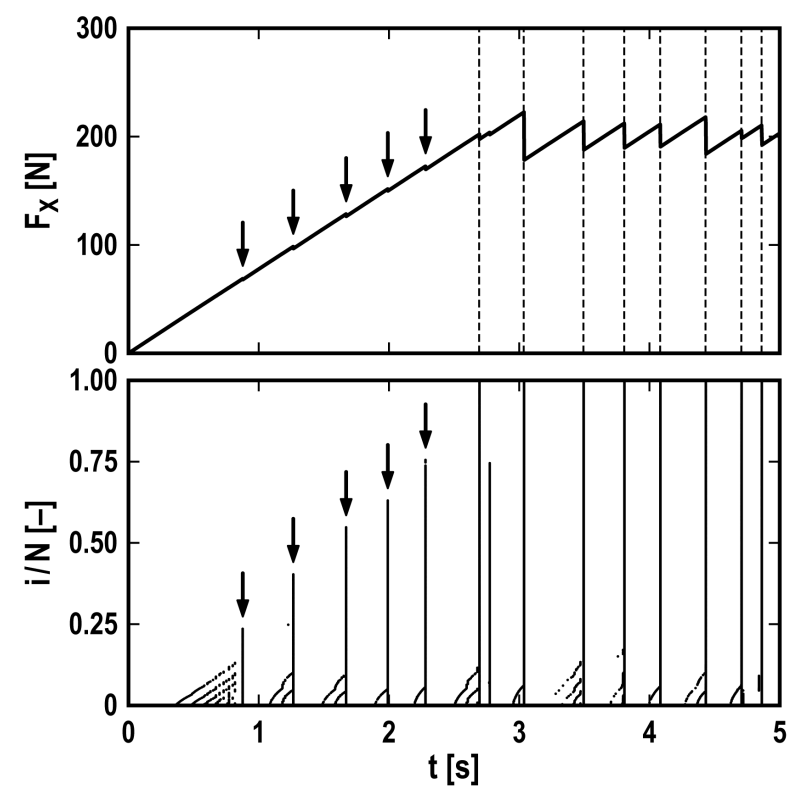

Fig. 6 Numerical results; temporal change in tangential load $F_{X}$ (upper) and temporal-spatial map of local slip (lower); arrow: precursor and broken line: global slip; $L=100 \mathrm{~mm}, S=200 \mathrm{~mm}^{2}, E=2.5 \mathrm{GPa}, M / L S=$ $1.2 \times 10^{3} \mathrm{~kg} / \mathrm{m}^{3}, K_{\mathrm{c}}^{\text {tot }}=1000 \mathrm{MN} / \mathrm{m}, K=0.8 \mathrm{MN} / \mathrm{m}, F_{Z}=400 \mathrm{~N}, V=0.1 \mathrm{~mm} / \mathrm{s}, \mu_{\mathrm{s}}=1.0, \mu_{\mathrm{k}}=0.5$, and $N=400$

$V=0.1 \mathrm{~mm} / \mathrm{s}$ とした.（このときバルク剛性は $K_{\mathrm{b}}^{\mathrm{tot}}=5 \mathrm{MN} / \mathrm{m}$ となる.）なお，上記の接触剛性 $K_{\mathrm{c}}{ }^{\mathrm{tot}}$ の值は，垂 直荷重 $400 \mathrm{~N}$ でベースブロックに接触させたスライダを（すべりが生じない程度に）打撃して，接線方向の 固有角振動数 $\omega$ を計測し, $K+K_{\mathrm{c}}^{\mathrm{tot}}=M \omega^{2}$ の関係 ${ }^{(11)} よ り$ 定めた. 各接触点に作用する真の静摩擦係数は, $\mu_{\mathrm{s}}=$ 1.0 と $\mu_{\mathrm{k}}=0.5$ を基準值とした. ブロックの総数 $N$ は, 単位長さあたりのブロック数が $N / L=4 \mathrm{~mm}^{-1}$ となるよ うに定めた。なお，すべてのばねが自然長 $\left(x_{i}=y_{i}=0\right)$ での静止状態を基準の初期条件とした。

\section{5. 数値解析結果}

\section{$5 \cdot 1$ 典型的な計算結果}

上記の基準值を用いた場合の計算結果を図 6 に示す。上段は $F_{X}$ の時間変化，下段は，縦軸に規格化された 接触点番号 $i / N$, 横軸に時刻 $t$ をとり，スリップ状態にある接触点に黒点をプロットして得た図である。巨視 すべり (図中の破線) に先立ち，5 回の前兆現象（図中の矢印）が発生し，引き続き鋸歯波状のスティック スリップが発生するというように，図３に示した実験結果が定性的によく再現されている.

ここで注目すべきは，垂直荷重 $F_{Z}=400 \mathrm{~N}$, 真の静摩擦係数 $\mu_{\mathrm{s}}=1$ での計算結果にもかかわらず，図 6 に現 れている $F_{X}$ の極大值（最大静摩擦力）の平均が $212 \mathrm{~N}$ となっている点である。これは，剛なスライダを仮定 した場合の最大静摩擦力 $\left(\mu_{\mathrm{s}} F_{Z}=400 \mathrm{~N}\right)$ の $53 \%$ にか満たない. 従って，スライダの弾性変形をともなうす ベり摩擦では, インターフェイスに作用する真の静摩擦係数 $\mu_{\mathrm{s}}$ とシステムに現れる実効的な静摩擦係数 $\mu_{\mathrm{s}}{ }^{\text {eff }}$ は必ずしも一致しないことがわかる。なお，実効的な動摩擦係数 $\mu_{\mathrm{k}}^{\mathrm{eff}}$ は，以後の計算結果を含む本稿の全条 件で，真の動摩擦係数 $\mu_{\mathrm{k}}$ と一致した.

\section{$5 \cdot 2$ 接線荷重の時間変化に及ぼすバルク剛性と接触剛性の影響}

バルク剛性 $K_{\mathrm{b}}^{\mathrm{tot}}$ と接触剛性 $K_{\mathrm{c}}^{\mathrm{tot}}$ の值を変えて同様の計算を行った。その結果を図 7 に示す。ただし， $K_{\mathrm{b}}{ }^{\mathrm{tot}}$

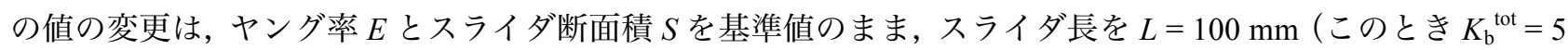
$\mathrm{MN} / \mathrm{m}$ ), $50 \mathrm{~mm}$ (このとき $K_{\mathrm{b}}{ }^{\mathrm{tot}}=10 \mathrm{MN} / \mathrm{m}$ )，または $25 \mathrm{~mm}$ (このとき $K_{\mathrm{b}}{ }^{\mathrm{tot}}=20 \mathrm{MN} / \mathrm{m}$ ）とした.

図 7 より，スティックスリップの振幅は， $K_{\mathrm{b}}^{\text {tot }}{ }^{\mathrm{t}} K_{\mathrm{c}}^{\mathrm{tot}}$ の両者に依存することがわかる。さらに， $\mu_{\mathrm{k}}^{\mathrm{eff}}$ は全条 件で $\mu_{\mathrm{k}}{ }^{\mathrm{eff}}=\mu_{\mathrm{k}}=0.5$ であつたことを考慮すると, 同図(a)より $\mu_{\mathrm{s}}{ }^{\text {eff }}$ は $K_{\mathrm{b}}{ }^{\text {tot }}$ と正の相関を持ち, 同図(b)より $\mu_{\mathrm{s}}{ }^{\text {eff }}$ は $K_{\mathrm{c}}^{\mathrm{tot}}$ と負の相関を持つことがわかる。 なお， $K_{\mathrm{b}}^{\text {tot }}$ は $L^{-1}$ に比例するので，同図(a)に現れている傾向は，図 4 


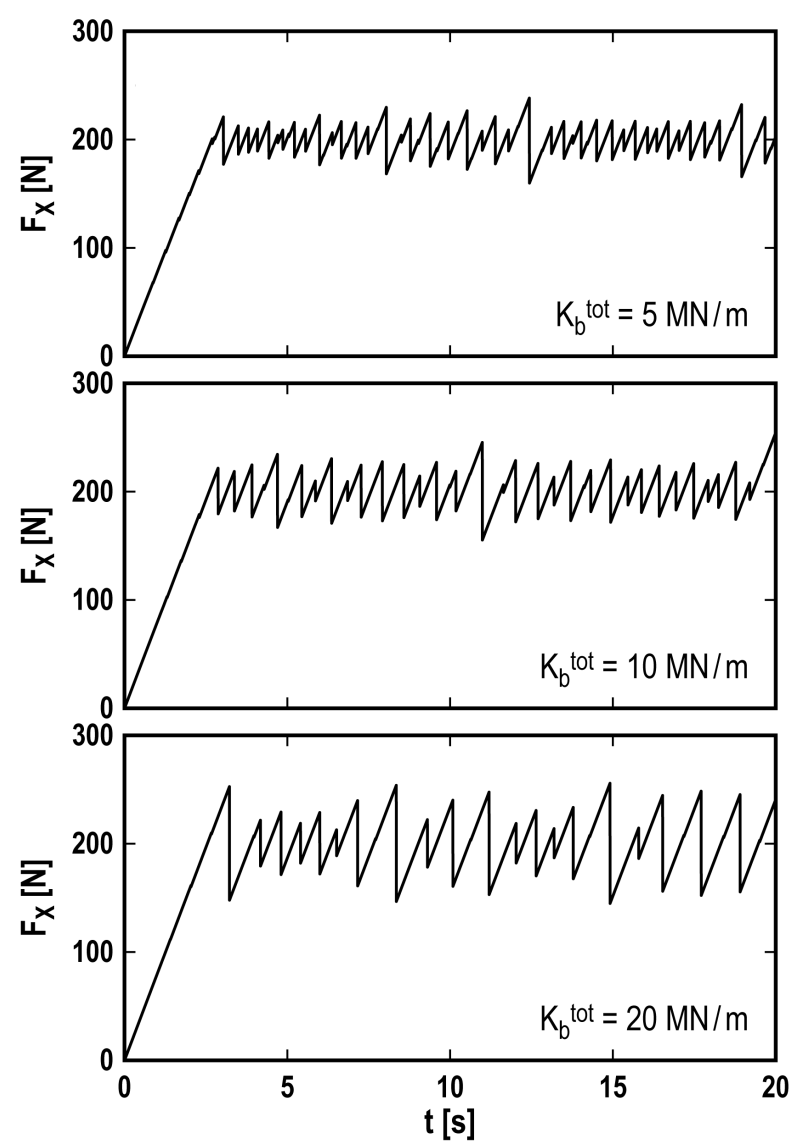

(a) Effect of total bulk stiffness $K_{\mathrm{b}}^{\text {tot }}$

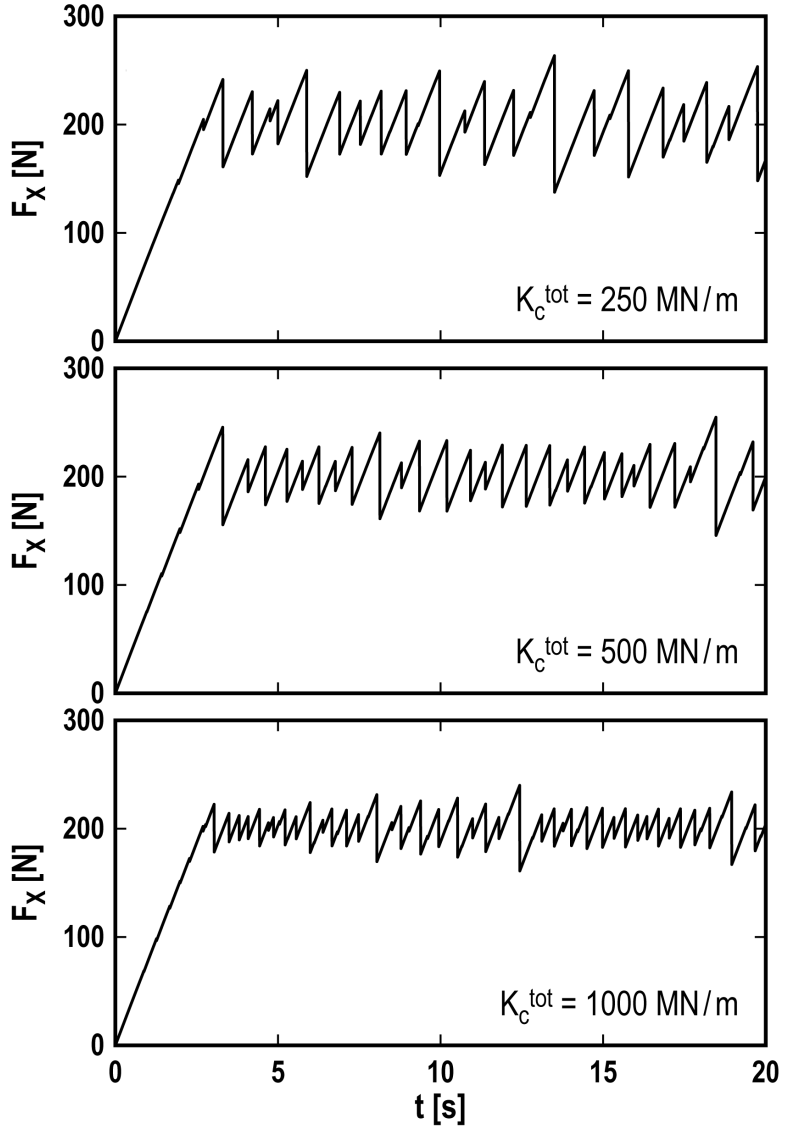

(b) Effect of total tangential contact stiffness $K_{\mathrm{c}}^{\text {tot }}$

Fig. 7 Numerical results; effects of total bulk stiffness $K_{\mathrm{b}}^{\text {tot }}$ (under $K_{\mathrm{c}}^{\text {tot }}=1000 \mathrm{MN} / \mathrm{m}$ ) and total tangential contact stiffness $K_{\mathrm{c}}^{\text {tot }}$ (under $K_{\mathrm{c}}^{\text {tot }}=5 \mathrm{MN} / \mathrm{m}$ ) on temporal change in tangential load $F_{X} ; S=200 \mathrm{~mm}^{2}, E=2.5 \mathrm{GPa}, M /$ $L S=1.2 \times 10^{3} \mathrm{~kg} / \mathrm{m}^{3}, K=0.8 \mathrm{MN} / \mathrm{m}, F_{Z}=400 \mathrm{~N}, V=0.1 \mathrm{~mm} / \mathrm{s}, \mu_{\mathrm{s}}=1.0$, and $\mu_{\mathrm{k}}=0.5$

の実験結果と定性的に一致している，以上の結果から，スライダの弾性変形をともなうすべり摩擦では，実 効的な静摩擦係数は，インターフェイスに作用する真の静摩擦係数のみで決まるのではなく，スライダの内 部変形を決めるバルク剛性と接触剛性に依存することがわかる.

\section{6. 考 察}

\section{$6 \cdot 1$ 剛性比の導入}

以上に示したように, Amundsen らのモデル（図 5）は弾性体のすべり摩擦の特徵をよく再現できている. そこで, 以後は同解析モデルに基づき, 実効的な静摩擦係数 $\mu_{\mathrm{s}}^{\mathrm{eff}}$ を支配するパラメー夕を考察して, 最終的 に $\mu_{\mathrm{s}}^{\mathrm{eff}}$ の設計式を導く.

まず，図 7 に示した計算結果に基づき，実効的な摩擦係数の差 $\left(\mu_{\mathrm{s}}^{\mathrm{eff}}-\mu_{\mathrm{k}}^{\mathrm{e}}{ }^{\mathrm{fff}}\right)$ とバルク剛性 $\left(K_{\mathrm{b}}{ }^{\mathrm{tot}}\right)$ および 接触剛性 $\left(K_{\mathrm{c}}^{\mathrm{tot}}\right)$ の関係を図 8 にまとめた。（ただし， $K_{\mathrm{b}}{ }^{\mathrm{tot}}$ の值の変更にあたっては，ヤング率 $E$ を基準值の まま，スライダ長を $L=25 \mathrm{~mm}, 50 \mathrm{~mm}, 100 \mathrm{~mm}$ ，スライダ断面積を $S=50 \mathrm{~mm}^{2}, 100 \mathrm{~mm}^{2}, 200 \mathrm{~mm}^{2}$ とした.） 同図の両対数グラフ上に認められる直線関係から， $\mu_{\mathrm{s}}^{\text {eff }}-\mu_{\mathrm{k}}{ }^{\text {eff }}$ と $K_{\mathrm{b}}^{\text {tot }}$ および $K_{\mathrm{c}}{ }^{\text {tot }}$ の間に幕乗則が認められる.

ここで，図 7 に示した近似曲線がほぼ平行かつ等間隔であることに着目して，剛性比 $\kappa$ :

$$
\kappa=\frac{K_{\mathrm{b}}^{\mathrm{tot}}}{K_{\mathrm{c}}^{\mathrm{tot}}}
$$

を導入する. 図 9 は, 縦軸に $\mu_{\mathrm{s}}^{\mathrm{eff}}-\mu_{\mathrm{k}}^{\mathrm{eff}}$, 横軸に $\kappa$ をとり, 図 8 に示した計算值を 1 枚の両対数グラフ上にま 


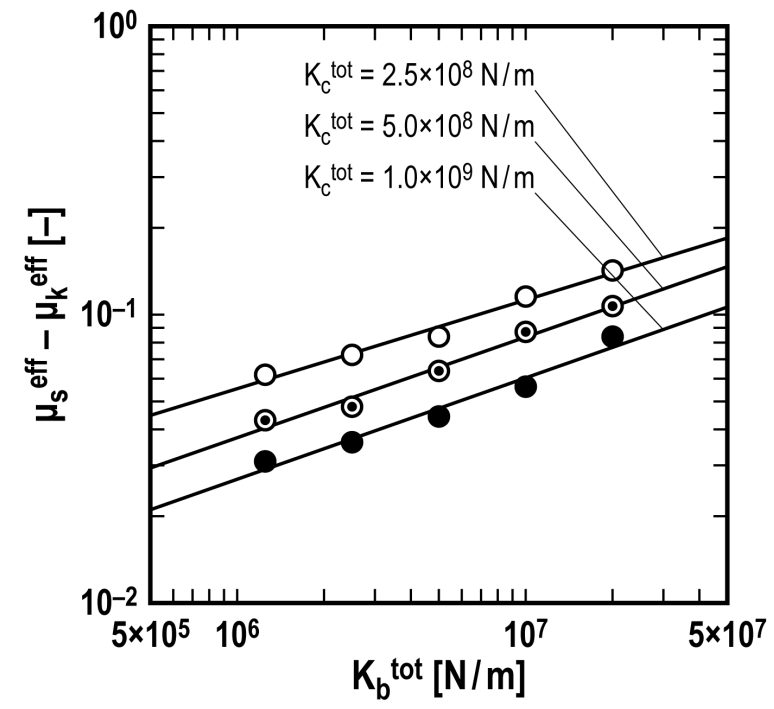

(a) Effect of total bulk stiffness $K_{\mathrm{b}}^{\text {tot }}$

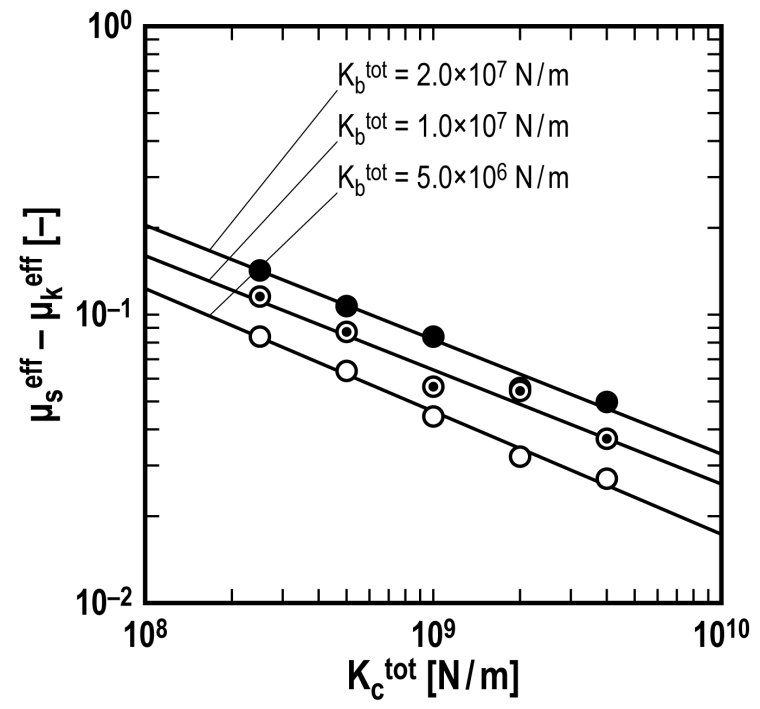

(b) Effect of total tangential contact stiffness $K_{\mathrm{c}}^{\text {tot }}$

Fig. 8 Numerical results; effects of total bulk stiffness $K_{\mathrm{b}}^{\text {tot }}$ and total tangential contact stiffness $K_{\mathrm{c}}^{\text {tot }}$ on $\mu_{\mathrm{s}}^{\text {eff }}-\mu_{\mathrm{k}}^{\text {eff }} ; E$ $=2.5 \mathrm{GPa}, M / L S=1.2 \times 10^{3} \mathrm{~kg} / \mathrm{m}^{3}, K=0.8 \mathrm{MN} / \mathrm{m}, F_{Z}=400 \mathrm{~N}, V=0.1 \mathrm{~mm} / \mathrm{s}, \mu_{\mathrm{s}}=1.0$, and $\mu_{\mathrm{k}}=0.5$

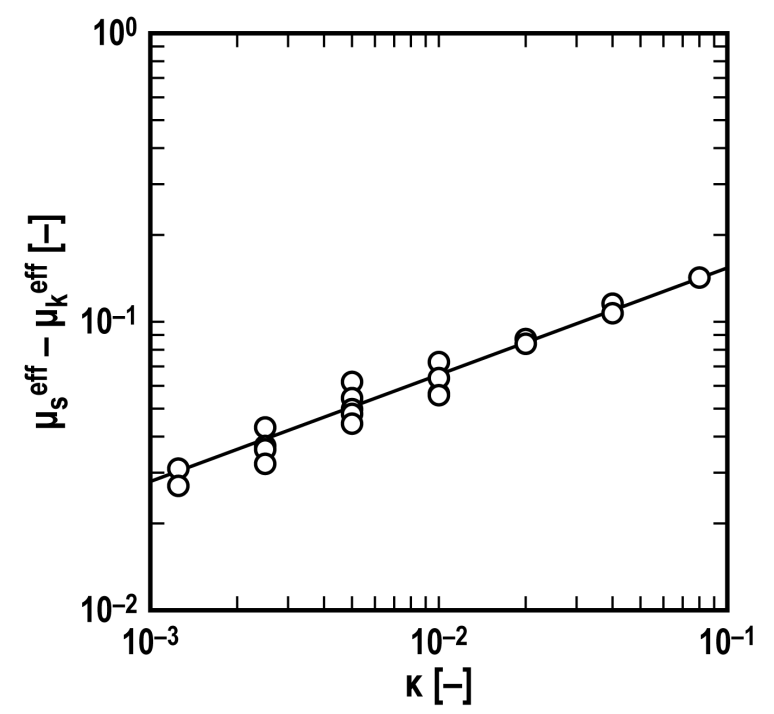

Fig. 9 Numerical results; relationship between $\mu_{\mathrm{s}}^{\text {eff }}-\mu_{\mathrm{k}}^{\text {eff }}$ and stiffness ratio $\kappa$; solid line: fitting curve (slope: 0.37)

とめたものである。すべての值が一直線上にスケールされていることから， $\mu_{\mathrm{s}}^{\mathrm{eff}}-\mu_{\mathrm{k}}^{\mathrm{eff}}$ と $\kappa$ の間に次の関係を 認めることができる。

$$
\mu_{\mathrm{s}}^{\mathrm{eff}}-\mu_{\mathrm{k}}^{\mathrm{eff}} \propto \kappa^{\beta}
$$

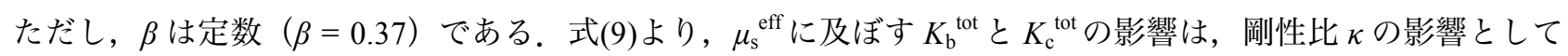
まとめられることがわかる.

\section{$6 \cdot 2$ 剛性比が実効的な静摩擦係数を決めるメカニズム}

式(8)で定義される剛性比 $\kappa$ は，式(4)と(5)を用いることにより，次のように変形することができる.

$$
\kappa=\frac{K_{\mathrm{b}}^{\mathrm{tot}}}{K_{\mathrm{c}}^{\text {tot }}}=\frac{E S}{L N k_{\mathrm{c}}}=\left(\frac{l_{0}}{L}\right)^{2}
$$



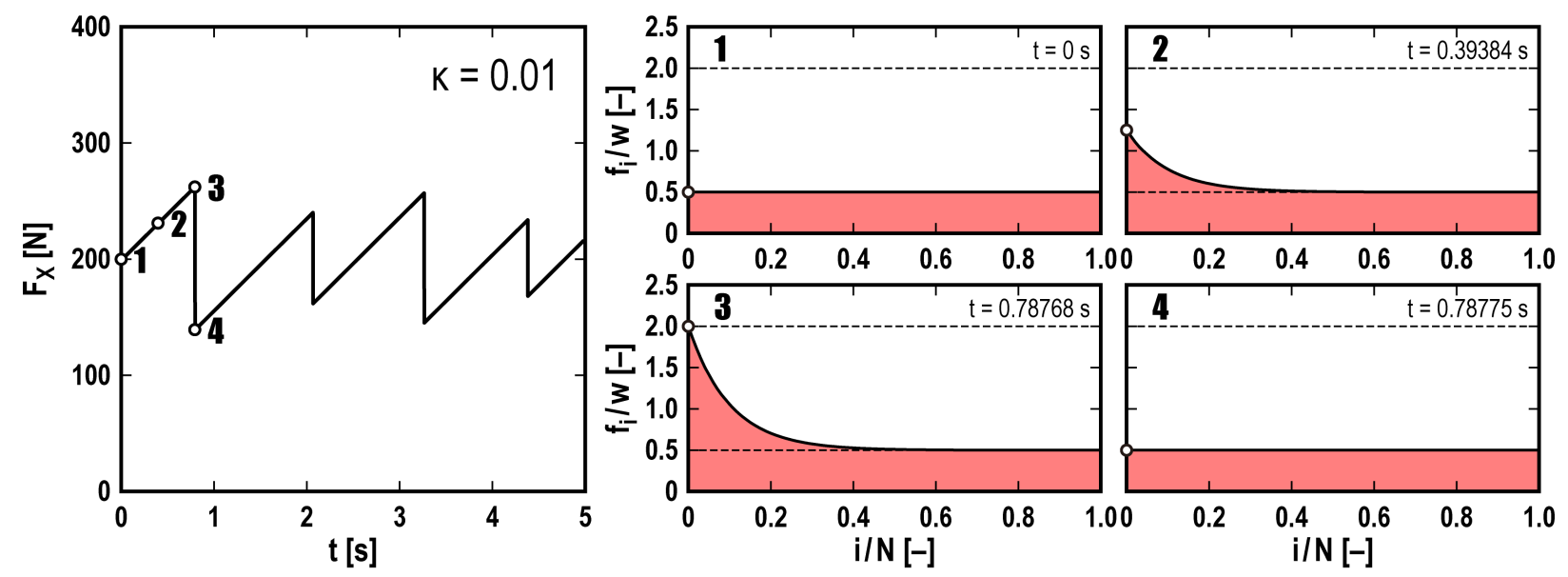

(a) $\kappa=0.01$
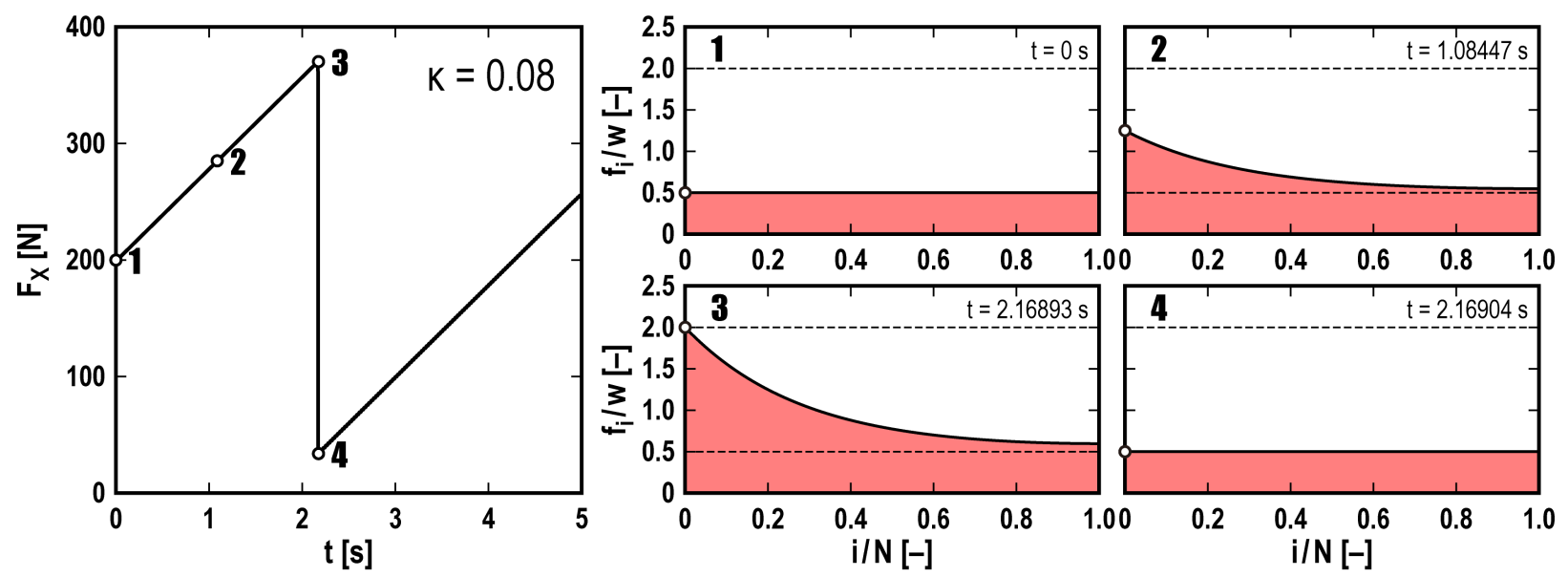

(b) $\kappa=0.08$

Fig. 10 Numerical results; temporal change of tangential load $F_{X}$ and snapshots of profile of $f_{i} / w$ for different values of stiffness ratio $\kappa=0.01$ and $0.08 ; S=200 \mathrm{~mm}^{2}, E=2.5 \mathrm{GPa}, M / L S=1.2 \times 10^{3} \mathrm{~kg} / \mathrm{m}^{3}, K=0.8 \mathrm{MN} / \mathrm{m}, F_{Z}=$ $400 \mathrm{~N}, V=0.1 \mathrm{~mm} / \mathrm{s}, \mu_{\mathrm{s}}=2.0$, and $\mu_{\mathrm{k}}=0.5$

ここで， $l_{0}$ は Amundsen ら ${ }^{(10)} に よ り$ 導入された長さの次元を持つ量 :

$$
l_{0}=\sqrt{\frac{L E S}{N k_{\mathrm{c}}}}
$$

であり，平衡状態にある系の全接触点を下面に固定したまま $F_{X}$ を準静的に加えるとき， $l_{0} / L \ll 1$ (すなわち $\kappa \ll 1 ）$ を満たす条件下において，スライダの左端から指数関数的に減少する $f_{i}$ のプロファイルを代表する緩 和長を表す。

図 10 は, $\kappa=0.01$ および 0.08 について, $F_{X}$ の時間変化と $f_{i} / w$ のプロファイルのスナップショットを示す. ただし，ここでは $\mu_{\mathrm{s}}=2.0$ および $\mu_{\mathrm{k}}=0.5$ のもと，すべてのブロックと接触点が平衡状態にある仮想的な巨視 すべりでの内部変形 :

$$
\left\{\begin{array}{c}
x_{i}=\frac{1}{2}(i-1)(i-2 N) \frac{\mu_{\mathrm{k}} w}{k} \\
y_{i}=x_{i}-\frac{\mu_{\mathrm{k}} w}{k_{\mathrm{c}}}
\end{array}\right.
$$






Fig. 11 Numerical results; relationship between effective static friction coefficient $\mu_{\mathrm{s}}^{\text {eff }}$ and stiffness ratio $\kappa$; solid line: Eq. (15) for $\alpha=0.72, \beta=0.37$, and $\gamma=1.06$

をブロックと接触点の初期変位として与え, 初速度はすべて零とした。(このとき結果的に前兆現象が発生せ ず, 初期状態から最初の巨視すべりまでの間, $f_{i}$ のプロファイルがなめらかになり, 現象の本質を把握するの に適した例題となる.)

図 10 に示した $\kappa=0.01$ および 0.08 のいずれの場合も，初期状態では $f_{i} / w=\mu_{\mathrm{k}}=0.5$ の一様なプロファイル を示しており (スナップショット 1 ), $F_{X}$ の増加とともに左端の值 $f_{1} / w$ が増加して, 指数関数的に減少する プロファイルが現れる (スナップショット 2). 左端の值が $f_{1} / w=\mu_{\mathrm{s}}=2.0$ に達すると (スナップショット 3 ), 左端の接触点に生じる固着すべり遷移をきっかけとして, 左端から右端へ剪断破壊が伝播して, 全接触点が 瞬時にスリップ状態となり，巨視すべりが現れる（スナップショット4).

ここで, $\kappa=0.01$ と 0.08 のスナップショット 3 を比較すると, 緩和長は前者の方が小さく, $f_{i} / w$ のプロフ アイルが左側に偏在していることがわかる，また，巨視すべりの直前までは準静的な状況とみなすことがで きるので, スナップショット 3 では $f_{i}$ の総和が $F_{X}$ に等しく, $F_{X}$ は $f_{i} / w$ のプロファイルの面積 (図中の塗りつ ぶした部分の面積）に比例する．以上を考慮すると， $\kappa=0.01$ での $\mu_{\mathrm{s}}^{\mathrm{eff}} と \kappa=0.08$ での $\mu_{\mathrm{s}}^{\text {eff }}$ の值が異なるメカ ニズムの本質は， $f_{i}$ のプロファイルの偏りにあることがわかる。すなわち, 剛性比 $\kappa$ を小さすると, 式(10) に従い緩和長 $l_{0}$ が小さくなり, $f_{i}$ のプロファイルが偏在化して, その総和を減じる効果を持つ. それが結果的 には実効的な最大静摩擦力を減じて， $\mu_{\mathrm{s}}^{\mathrm{eff}}$ を低下させる効果を持つ.

なお，剛なスライダの場合には，巨視すべりの直前において，全接触点が $f_{i} / w=\mu_{\mathrm{s}}=2.0$ となり，この状況 に限り, $\mu_{\mathrm{s}}^{\mathrm{e} f f}=\mu_{\mathrm{s}}$ となる，一方，スライダが弾性変形する場合には，一般に巨視すべりの直前で $f_{i} / w<\mu_{\mathrm{s}}=2.0$ となる接触点が存在するので, 必然的に $\mu_{\mathrm{s}}^{\text {eff }}<\mu_{\mathrm{s}}$ となり, 実効的な静摩擦係数は真の静摩擦係数よりも低く 現れる。

\section{$6 \cdot 3$ 実効的な静摩擦係数の設計式}

実効的な摩擦係数は, バルクの変形を特徵づける剛性比 $\kappa$ だけでなく, 真の摩擦係数にも依存すると予想 される. そこで, 先に式(9)を得たように, 両対数グラフ上において, 縦軸に実効的な摩擦係数の差 $\mu_{\mathrm{s}}^{\text {eff }}-\mu_{\mathrm{k}}{ }^{\text {eff }}$, 横軸に真の摩擦係数の差 $\mu_{\mathrm{s}}-\mu_{\mathrm{k}}$ をとつ両者の関係を調べたところ, 次の関係式を得た.

$$
\mu_{\mathrm{s}}^{\mathrm{eff}}-\mu_{\mathrm{k}}^{\mathrm{eff}} \propto\left(\mu_{\mathrm{s}}-\mu_{\mathrm{k}}\right)^{\gamma}
$$

ただし， $\gamma$ は定数（ $\gamma=1.06 ）$ である. 


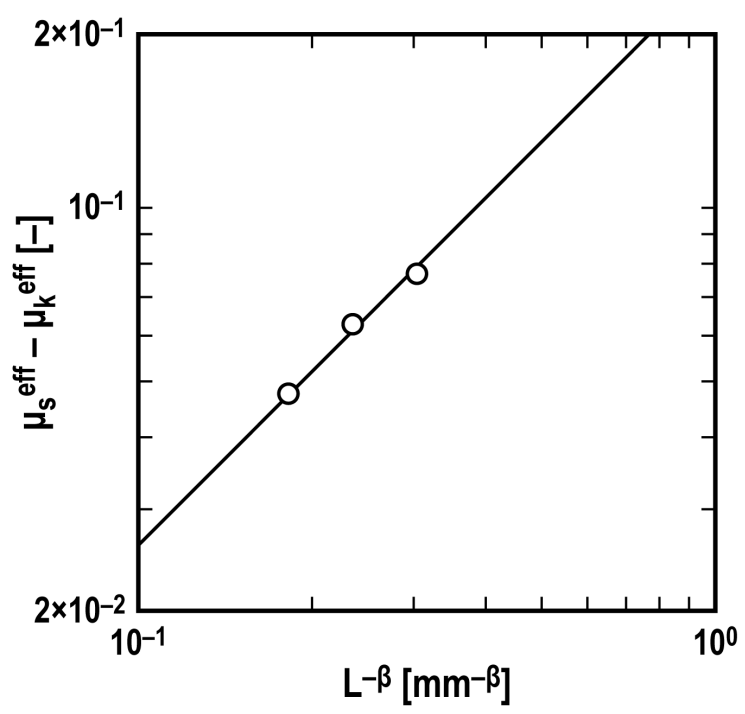

Fig. 12 Experimental results; relationship between $\mu_{\mathrm{s}}^{\text {eff }}-\mu_{\mathrm{k}}^{\text {eff }}$ and $L^{-\beta}(\beta=0.37)$; solid line: fitting curve with a slope of unity

以上に得られた式(9)と(13)をまとめると，次の関係式が得られる。

$$
\mu_{\mathrm{s}}^{\mathrm{eff}}-\mu_{\mathrm{k}}^{\mathrm{eff}}=\alpha \kappa^{\beta}\left(\mu_{\mathrm{s}}-\mu_{\mathrm{k}}\right)^{\gamma}
$$

ただし， $\alpha$ は定数である.さらに，真の動摩擦係数と実効的な動摩擦係数が一致したことを考慮すると，実 効的な静摩擦係数を与える次の設計式を最終的に得る。

$$
\mu_{\mathrm{s}}^{\mathrm{eff}}=\mu_{\mathrm{k}}+\alpha \kappa^{\beta}\left(\mu_{\mathrm{s}}-\mu_{\mathrm{k}}\right)^{\gamma}
$$

図 11 は， $\kappa \ll 1$ の範囲で，スライダの剛性を決めるパラメータ $\left(L, S, K_{\mathrm{c}}^{\mathrm{tot}}\right)$ と接触点に働く真の静摩擦 係数 $\left(\mu_{\mathrm{s}}\right)$ の值をそれぞれ変えて, 合計 60 条件での実効的な静摩擦係数 $\left(\mu_{\mathrm{s}}^{\text {eff }}\right)$ の值を計算し, $\mu_{\mathrm{s}}^{\text {eff }}$ と $\kappa$ の関 係をまとめたものである。ただし, 図中の曲線は, 式(15)（ただし， $\alpha=0.72, \beta=0.37, \gamma=1.06)$ を表す。い くらかのばらつきはあるものの，すべての計算結果が曲線の近くに位置していることから，少なくとも今回 の計算条件の範囲では，式(15)の妥当性が認められる.

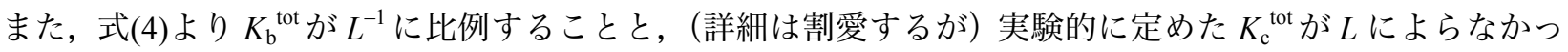
たことを考慮すると， $\kappa$ は $L^{-1}$ に比例すると考えてよい，そこで，実験的に得られた $\mu_{\mathrm{s}}^{\mathrm{eff}}-\mu_{\mathrm{k}}^{\mathrm{eff}}$ 縦軸， $L^{-\beta}$ を 横軸にとって整理すると，図 12 が得られる，実験的に得た 3 点の值は，式(9)および式(14)が示すとおり，傾 き1の直線付近に位置することから，本考察を通して得た $\mu_{\mathrm{s}}^{\mathrm{eff}}$ の設計式の妥当性を支持している.

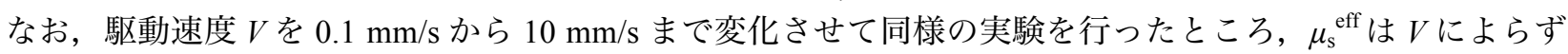
一定であった。これは，本研究で対象としたアクリル製のスライダとベースブロックのすべり摩擦では，摩 擦力の駆動速度依存性を生む内部減衰の効果（=広義のヒステリシス摩擦）に比べて凝着摩擦が支配的であ ったことを意味する。しかし，鋼球とゴム平板のすべり摩擦など，内部減衰を無視することができない場合 には，このたび得た設計式(15)に修正が必要であると考えられる。

また，垂直荷重 $F_{Z}$ を $100 \mathrm{~N}$ から $400 \mathrm{~N}$ まで変化させて同様な実験を行ったところ, $\mu_{\mathrm{s}}^{\text {eff }}$ は $F_{Z}$ に対して負の 依存性を示した。(同様の結果は，David らの実験(5)においても観察されている。) これらの実験事実は， $K_{\mathrm{c}}^{\mathrm{tot}}$

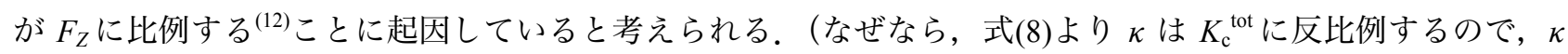
は $F_{Z}$ に反比例する。この関係を式(15)に代入すれば, $\mu_{\mathrm{s}}^{\text {eff } か ゙ ~} F_{Z}$ に対して負の依存性が現れることを説明でき る.）今後の詳細な検討は必要だが，このたび得た設計式(15)は，接線方向の接触剛性の変化を通して，実効 的な静摩擦係数の垂直荷重依存性 ${ }^{(13)}$ をる程度まで表現していると考えられる. 


\section{7. 結 言}

アクリル製のスライダとベースブロックのすベり摩擦を対象とした実験と数值解析を通して，スライダの 弾性変形に着目した静摩擦係数の設計指針を検討した. その結果, 実効的な静摩擦係数を決める要因として, スライダの弾性的な内部変形と接触部を伝播する剪断破壞の重要性を改めて確認するとともに, 実効的な静 摩擦係数の值を支配する因子として, スライダのバルク剛性と接線方向の接触剛性の比の存在を見出した.

本検討を通して最終的に得た設計式(15)には，所望の摩擦係数を得るための指針について，冒頭に述べた ふたつのコンセプトが含まれている.すなわち, 真の摩擦係数 $\left(\mu_{\mathrm{s}}\right.$ と $\left.\mu_{\mathrm{k}}\right)$ からのアプローチは「インターフ エイスのミクロな性質に着目した摩擦の設計」に相当し, 剛性比 $(\kappa)$ からのアプローチは「バルクのマクロ な変形に着目した摩擦の設計」に相当する。これらふたつのコンセプトを併用することにより，機械システ ムの摺動部に必要となる実効的な静摩擦係数の設計が，従来よりも柔軟になることが期待される.

\section{文献}

(1) Nakano, K., "Two dimensionless parameters controlling the occurrence of stick-slip motion in a 1-DOF system with Coulomb friction”, Tribology Letters, Vol. 24, No. 2 (2006), pp. 91-98.

(2) Nakano, K., and Maegawa, S., "Safety-design criteria of sliding systems for preventing friction-induced vibration", Journal of Sound and Vibration, Vol. 324, No. 3-5 (2009), pp. 539-555.

(3) Nakano, K., and Maegawa, S., "Occurrence limit of stick-slip: dimensionless analysis for fundamental design of robust stable systems", Lubrication Science, Vol. 22, No. 1 (2010), pp. 1-18.

(4) Maegawa, S., Suzuki, A., and Nakano, K., "Precursors of global slip in a longitudinal line contact under non-uniform normal loading", Tribology Letters, Vol. 38, No. 3 (2010), pp. 313-323.

(5) David, O.B., and Fineberg, J., "Static friction coefficient is not a material constant", Physical Review Letters, Vol. 106, No. 25 (2011), 254301.

(6) Trømborg, J., Scheibert, J., Amundsen, D.S., Thøgersen, K., and Sørenssen, A.M., "Transition from static to kinetic friction: insights from a 2D model”, Physical Review Letters, Vol. 107, No. 7 (2011), 074301.

(7) Rubinstein, S.M., Cohen, G., and Fineberg, J., "Detachment fronts and the onset of dynamic friction", Nature, Vol. 430, No. 7003 (2004), pp. 1005-1009.

(8) Rubinstein, S.M., Shay, M., Cohen, G., and Fineberg, J., "Crack-like processes governing the onset of frictional slip”, International Journal of Fracture, Vol. 140, No. 1-4 (2006), pp. 201-212.

(9) Rubinstein, S.M., Cohen, G., and Fineberg, J., "Dynamics of precursors to frictional sliding", Physical Review Letters, Vol. 98, No. 22 (2007), 226103.

(10) Amundsen, D.S., Scheibert, J., Thøgersen, K., Trømborg, J., and Sørenssen, A.M., "1D model of precursors to frictional stick-slip motion allowing for robust comparison with experiments", Tribology Letters, Vol. 45, No. 2 (2012), pp. 357-369.

(11) Nakano, K., and Maegawa, S., "Stick-slip in sliding systems with tangential contact compliance", Tribology International, Vol. 42, No. 11-12 (2010), pp. 1771-1780.

(12) Berthoud, P., and Baumberger, T., "Shear stiffness of a solid-solid multicontact interface", Proceedings of the Royal Society A, Vol. 454, No. 1974 (1998), pp. 1615-1634.

(13) Otsuki, M., and Matsukawa, H., "Systematic breakdown of Amontons' law of friction for an elastic object locally obeying Amontons' law”, Scientific Reports, Vol. 3 (2013), 1586. 